\section{Nonenzymatic Addition of Glucocorticoids to Lens Proteins in Steroid-induced Cataracts}

Shigeo Manabe, Richard Bucala, and Anthony Cerami Laboratory of Medical Biochemistry, The Rockefeller University, New York, NY 10021

formation of these cataracts is a well-documented phenomenon $(2,3)$ and is observed in nearly all patients who receive $20 \mathrm{mg}$ prednisone/d for $4 \mathrm{yr}$ for the treatment of rheumatoid arthritis (4). Cataractogenesis correlates well with the dosage and duration of therapy and generally halts after the withdrawal of steroids.

Glucocoticoid-binding proteins in the lens have been described $(5,6)$, but the precise biochemical mechanism involved in cataract formation has not been found. We recently have demonstrated that steroids possessing a ketol moiety can react with protein amino groups to form stable covalent adducts (7). The steroid-protein adduct is stable to dialysis and gel filtration, indicating that the off-rate is extremely slow. In the case of glucocorticoids, a Schiff base presumably forms at the C-20 carbonyl, and the C-21 hydroxyl then participates in Heyns rearrangement to produce a stable ketoamine product. Fig. 1 shows this proposed reaction scheme for the glucocorticoid prednisolone. This mechanism is analogous to the nonenzymatic reaction of $16 \alpha$-hydroxyestrone with protein amino groups (7), which recently has been shown to occur in vivo with membrane proteins (8).

In this report we have investigated the possibility that elevated glucocorticoid levels lead to the formation of glucocorticoid-lens protein adducts and that these adducts correlate with the development of cataracts. Whole rate lenses, when incubated with prednisolone in vitro, were observed to develop opacification in a time- and concentration-dependent manner. The formation of prednisolone-protein adducts was detected in these lenses and analyzed by the incorporation of $\left[{ }^{3} \mathrm{H}\right]$ prednisolone into lens proteins and by immunoprecipitation with antiserum specific for the prednisolone hapten. In a competitive radioimmunoassay with this same antiserum, glucocorticoid-modified proteins also were detected in enzymatic hydrolysates from glucocorticoid-induced cataractous human lenses.

\section{Methods}

Reagents and animals. Human serum albumin fraction $\mathrm{V}$, cortisol, $17 \beta$-estradiol, etiocholanolone, and prednisone were purchased from Sigma Chemical Co. (St. Louis, MO). Proteinase $\mathrm{K}$ was from Boehringer Mannheim Biochemicals (Mannheim, West Germany). Dehydroepiandrosterone was the gift of Dr. Jack Fishman (Rockefeller University, New York) and all other steroids were obtained from Steraloids (Wilton, NH). $\left[2,4,5,7,{ }^{3} \mathrm{H}\right]$ Prednisolone $\left(61 \mathrm{Ci} / \mathrm{mmol}\left[1 \mathrm{Ci}=3.7 \times 10^{10}\right.\right.$ 

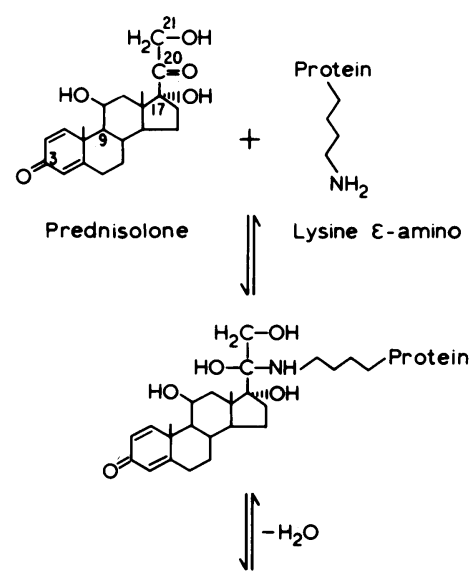

Addition Product

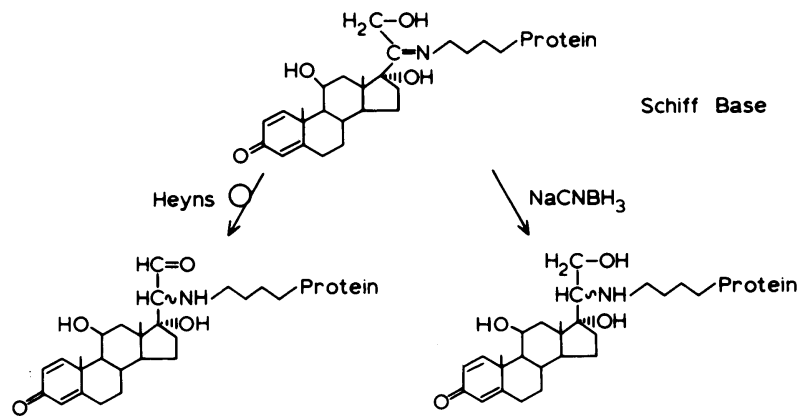

Figure 1. The reaction scheme between the glucocorticoid, prednisolone, and the lysine residues of proteins, showing the adducts formed by the proposed Heyns rearrangement and by the addition of $\mathrm{NaCNBH}_{3}$.

Bq] was obtained from Amersham (Arlington Heights, IL) and stored at $-20^{\circ} \mathrm{C}$. Radiochemical purity was monitored by reverse-phase high performance liquid chromatography as described previously (7). Male Sprague-Dawley rats $(70-90 \mathrm{~g})$ were obtained from Taconic Farms (Germantown, NY).

Lens culture. Rat lenses were excised and washed at room temperature with medium 199 (Gibco Laboratories, Grand Island, NY) supplemented with $5 \%$ heat inactivated fetal bovine serum, $100 \mathrm{U} / \mathrm{ml}$ penicillin $\mathrm{G}$, and $25 \mu \mathrm{g} / \mathrm{ml}$ amphotericin B. Lenses were cultured on wire grids (9) in $1 \times 3.5 \mathrm{~cm}$ tissue culture wells in medium 199 containing $5 \%$ heat-inactivated fetal calf serum and $100 \mathrm{U} / \mathrm{ml}$ penicillin G. Each well contained two to three lenses. Incubation was at $37^{\circ} \mathrm{C}$ in a humidified incubator containing an atmosphere of $5 \% \mathrm{CO}_{2}$ and balanced air.

Glucocorticoids were dissolved in culture media containing $10 \%$ ethanol and $3 \mu \mathrm{l}$ added to each well, yielding a final concentration of $0.01 \%$ ethanol and either $5-50 \mathrm{nM}$ glucococorticoid or $35 \mu \mathrm{Ci} / \mathrm{ml}$ $\left[{ }^{3} \mathrm{H}\right]$ prednisolone $(5 \mathrm{nM})$. Control media used in steroid-free incubations contained $0.01 \%$ ethanol as well. Culture medium was replaced on alternate days. Reverse-phase high performance liquid chromatography analysis of the culture media after $48 \mathrm{~h}$ demonstrated that $<4 \%$ of the added $\left[{ }^{3} \mathrm{H}\right]$ prednisolone had undergone conversion to other compounds.

Fractionation of lens proteins. Lens proteins were fractionated with modifications of the procedure described by Kramps et al. (10). Three rat lenses were pooled in an ice-cold glass tissue homogenizer that

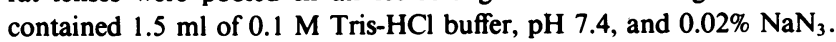

The lenses were homogenized under a nitrogen stream with eight strokes of a ground glass pestle. The mixture was centrifuged at 20,000 $g$ for $30 \mathrm{~min}$ at $4^{\circ} \mathrm{C}$, and the supernatant solution (water-soluble fraction) stored at $4^{\circ} \mathrm{C}$ under nitrogen. The sediment was resuspended

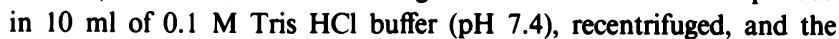
supernatant removed. The washed sediment was then resuspended in $1.5 \mathrm{ml}$ of $0.1 \mathrm{M}$ Tris- $\mathrm{HCl}$ buffer ( $\mathrm{pH} 7.4$ ), containing $7 \mathrm{M}$ urea and $0.02 \% \mathrm{NaN}_{3}$. This material was vortexed at intervals and allowed to stand for $1 \mathrm{~h}$ at $4^{\circ} \mathrm{C}$. After centrifugation as above, the supernatant solution (urea-soluble fraction) was stored under $100 \% \mathrm{~N}_{2}$ at $4^{\circ} \mathrm{C}$. The urea-insoluble fraction was resuspended in $10 \mathrm{ml}$ of the same buffer and washed one additional time. The amount of total protein in the soluble fractions was determined by the method of Bradford (11), using dye reagent supplied by Bio-Rad Laboratories (Richmond, CA) and lyopholized bovine serum albumin as a standard. Urea-insoluble protein was measured after solubilization in sodium dodecyl sulfate (SDS) and dialysis as described below.

Water-soluble and urea-soluble fractions were dialyzed overnight (cutoff, 3,500 mol wt) at room temperature against a buffer containing $0.1 \mathrm{M}$ Tris- $\mathrm{HCl}, \mathrm{pH} 6.8,10 \mathrm{mM} \beta$-mercaptoethanol and $0.1 \%$ SDS. The urea-insoluble fraction was first dissolved in a minimum volume of $10 \mathrm{mM}$ Tris-HCl buffer (pH 6.8) containing $10 \mathrm{mM} \beta$-mercaptoethanol, $1 \mathrm{mM}$ EDTA, and 4\% SDS before dialysis.

SDS-polyacrylamide gel electrophoresis. Dialyzed lens protein fractions were analyzed for radioactivity and total protein and then diluted $1: 1$ in a sample buffer containing $0.1 \mathrm{M}$ Tris- $\mathrm{HCl}$ buffer $\mathrm{pH} 6.8,40 \%$ glycerol, $40 \mathrm{mM}$ DTT, $2 \mathrm{mM}$ EDTA, $1 \%$ SDS, and $0.02 \%$ bromophenol blue. The mixtures were heated at $100^{\circ} \mathrm{C}$ for $3 \mathrm{~min} .25 \mu \mathrm{g}$ of protein containing $\sim 5,000 \mathrm{cpm}$ of tritium was loaded on polyacrylamide slab gels containing $13 \%$ acrylamide and $0.35 \%$ bisacrylamide and electrophoresed in the presence of $0.1 \%$ SDS using the buffer system described by Laemmli (12). The protein standard mixture (low molecular weight) was obtained from Bio-Rad Laboratories. Gels were stained for protein with Coomassie Brilliant Blue R-250 and then fluorographed (13) to localize tritium incorporation. Exposures were performed at $-80^{\circ} \mathrm{C}$ with Kodak X-OMAT AR5 X-ray film (Eastman Kodak Co., Rochester, NY).

Radioimmunoassay procedure. Synthetic prednisolone-protein adducts were prepared using methods described previously for the synthesis of $16 \alpha$-hydroxyestrone modified albumin (14). Briefly, $50 \mu l$ of a 12.6$\mathrm{mg} / \mathrm{ml}$ solution of prednisolone was added to a $0.45-\mathrm{ml}$ solution of human serum albumin in $50 \mathrm{mM}$ potassium phosphate buffer, $\mathrm{pH}$ 7.4, containing $10 \%$ ethanol. $10 \mu \mathrm{l}$ of a $1-\mathrm{M}$ solution of $\mathrm{NaCNBH}_{3}$ was then added and the solution incubated for $6 \mathrm{~d}$ at $37^{\circ} \mathrm{C}$. To calculate the degree of prednisolone incorporation, a second mixture was prepared that contained, in addition, $4 \times 10^{5} \mathrm{cpm}$ of $\left[{ }^{3} \mathrm{H}\right]$ prednisolone. Unbound material was separated by extensive dialysis against a buffer of $50 \mathrm{mM}$ potassium phosphate $\mathrm{pH} 7.4$ containing $10 \%$ ethanol, and gel filtration over a column of Sephadex G-100, equilibrated with the same buffer. A molar ratio of prednisolone to human serum albumin of 3.1:1 was obtained.

Antisera to the $\mathrm{NaCNBH}_{3}$-reduced prednisolone-albumin conjugate were raised in New Zealand white rabbits using immunization procedures described previously (14). Similar antibody titers to prednisolonealbumin were observed in the two rabbits immunized. Radioimmunoassays were performed in $1.5-\mathrm{ml}$ microfuge tubes (Brinkmann Instruments, Westbury, NY) that contained the test antigen in $100 \mu \mathrm{l}$ of a buffer composed of $50 \mathrm{mM}$ Tris- $\mathrm{HCl}(\mathrm{pH} 8.0), 100 \mathrm{mM} \mathrm{NaCl}$, $0.1 \%$ gelatin, and $0.02 \% \mathrm{NaN}_{3}$. Diluted antiserum $(200 \mu \mathrm{l})$ that contained $5,000 \mathrm{cpm}$ of $\left[{ }^{3} \mathrm{H}\right]$ prednisolone was then added, the samples 
incubated at $4^{\circ} \mathrm{C}$ for $12-16 \mathrm{~h}$, and antibody-bound material separated from free material by precipitation with $50 \%$ saturated ammonium sulphate. The optimal dilution of antisera that bound $50 \%$ of the 94 fmol of $\left[{ }^{3} \mathrm{H}\right]$ prednisolone present in the assay was found to be 1:3,000. The application constant $\left(K_{\mathrm{A}}\right)$ for the binding of prednisolone was calculated by Scatchard analysis to be $8.7 \times 10^{8} \mathrm{M}^{-1}$. Antiserum specificity was tested by assaying various steroids, synthetic prednisoloneprotein adducts, and enzymatically digested adducts for cross-reactivity. The molar amount required to reduce the binding of $\left[{ }^{3} \mathrm{H}\right]$ prednisolone by $50 \%$ compared with unlabeled prednisolone was calculated from the standard curve. Sensitivity was defined as the value of two standard deviations of the mean of duplicate blank values (15).

Noncovalently bound material was removed from human lens protein fractions by dialysis against a buffer containing SDS (described below), or by extraction with ethyl ether (three times). The efficiency of extraction was estimated by adding a standard amount of $\left[{ }^{3} \mathrm{H}\right]$ prednisolone $(3,000 \mathrm{cpm})$ to the protein fraction and counting the extractable tritium. Recoveries of $>95 \%$ of the added tritium were consistently observed. A portion of the lens protein fraction was subjected to radioimmunoassay while another portion was assayed after digestion with proteinase $\mathrm{K}$ (described below). Identical values were obtained with the dialyzed and the ether-extracted protein samples.

Immunoprecipitation of cultured rat lens proteins. Dialyzed protein fractions were obtained from lenses cultured in the presence of $\left[{ }^{3} \mathrm{H}\right]$ prenisolone and digested by incubating a $50-\mu \mathrm{l}$ aliquot with $50 \mu \mathrm{l}$ of $1 \mathrm{mg} / \mathrm{ml}$ proteinase $\mathrm{K}$ at $37^{\circ} \mathrm{C}$ (described below). The reaction was terminated after $1 \mathrm{~h}$ by adding $100 \mu \mathrm{l}$ of $0.1 \mathrm{M}$ Tris- $\mathrm{HCl}$ buffer, $\mathrm{pH}$ 7.4 containing $7 \mathrm{M}$ urea and $0.02 \% \mathrm{NaN}_{3} .200 \mu \mathrm{l}$ of antiserum $(1: 3,000)$ was then added to each sample. The blank samples contained normal rabbit serum at the same dilution. Samples were incubated at $4^{\circ} \mathrm{C}$ for $10 \mathrm{~h}$. Bound material was separated by adding $0.8 \mathrm{ml}$ of a saturated ammonium sulphate solution and collecting the precipitate by centrifugation for $10 \mathrm{~min}$ in an Eppendorf microfuge (model 1514, Brinkmann, Westbury, NY). Aliquots from the soluble fraction were removed and analyzed for radioactivity by liquid scintillation counting.

Enzymatic hydrolysis. Water-soluble proteins were digested by adding $5 \mathrm{mg}$ of protein to an equal volume of digestion buffer $(0.1 \mathrm{M}$ Tris- $\mathrm{HCl}, \mathrm{pH} 8.8$ containing $1 \mathrm{mM}$ EDTA and $1 \mathrm{mM}$ DTT) and adding $1 \mathrm{mg} / \mathrm{ml}$ proteinase $\mathrm{K}(16)$. The urea-soluble fraction was digested by first adding a twofold volume excess of $0.1 \mathrm{M}$ Tris- $\mathrm{HCl}$ buffer, $\mathrm{pH}$ 8.8. This dilution reduces the urea concentration to a degree that does not inhibit protease activity. The urea-insoluble fractions were solubilized by resuspending in $1 \mathrm{ml}$ of the digestion buffer containing proteinase $\mathrm{K}$. All digestions were carried out at $37^{\circ} \mathrm{C}$. The extent of digestion was estimated by the generation of ninhydrin positive material (17). Proteolysis was judged to be complete at $1 \mathrm{~h}$. The reactions were terminated by adding $1 \mathrm{ml}$ of $0.1 \mathrm{M}$ Tris- $\mathrm{HCl}$ containing $7 \mathrm{M}$ urea. Aliquots of digested samples were then subjected to radioimmunoassay and immunoprecipitation as described above.

Human lens specimens. Normal human lenses were obtained from the Eye-Bank for Sight Restoration, Inc. (New York, NY). The assayed samples $(n=9)$ were from individuals aged 41 to $69 \mathrm{yr}$. The diabetic $(n=5)$, traumatic $(n=1)$, and senile $(n=11)$ cataractous lenses were from the New York Hospital, Department of Surgical Pathology. The diabetic cataracts were from patients of ages 59 to 62 years. Three of these lenses were from individuals with type 1 diabetes mellitus who also suffered from complications of retinopathy and nephropathy. The senile cataracts were obtained from patients of ages 59 to $87 \mathrm{yr}$. No additional conditions known to contribute to cataract formation were present in these cases.
The glucocorticoid-induced cataractous lenses $(n=7)$ were the generous gifts of Drs. A. J. Bron, J. J. Harding, and V. Monnier. Relevant clinical information is summarized below.

Lens $A$. A 67-yr-old male patient with rheumatoid arthritis and chronic bronchitis received $5-7.5 \mathrm{mg}$ prednisolone/d for at least $10 \mathrm{yr}$ In addition, this patient received $7.5 \mathrm{mg}$ cortisone/d for $1 \mathrm{yr}$. Other likely steroid-induced complications included glaucoma and peptic ulcer. Lens B. A 72-yr-old female patient with sarcoidosis received an ophthalmic preparation of $0.125 \%$ prednisolone phosphate two times per day for $\sim 8 \mathrm{yr}$. This patient also suffered from glaucoma. Lens $C$. A 73-yr-old female with rheumatoid arthritis received a minimum of $5 \mathrm{mg}$ of prednisolone per day for $5 \mathrm{yr}$. During this time the patient also received alternate day therapy of $0.6 \mathrm{mg}$ of betamethasone. Lens $D$. A 61-yr-old male with bronchial asthma received a minimum of $10 \mathrm{mg}$ of prednisolone per day for more than $10 \mathrm{yr}$. Lens $E$. A 74-yrold male with bronchial asthma received a minimum of $5 \mathrm{mg}$ of prednisolone for 5 yr. Lens $F$. A 56-yr-old female patient with rheumatoid arthritis and anterior uveitis received an ophthalmic preparation of $0.125 \%$ prednisolone phosphate four times per day for $2 \mathrm{yr}$ In addition, dexamethasone ointment was given three times per day for 2 yr. Lens $G$. A 75-yr-old female patient with bronchial asthma, glaucoma, and diabetes mellitus (type II). This patient received $2.5 \mathrm{mg}$ of prednisolone for $5 \mathrm{yr}$.

In all cases, nuclear sclerosis and posterior subcapsular changes were evident by ophthalmological examination. Lenses A-C were lyophilized and stored at $4^{\circ} \mathrm{C}$. Lenses D-G were received whole and stored at $-20^{\circ} \mathrm{C}$.

\section{Results}

The interaction of lenses with glucocorticoids was studied initially in an in vitro system using whole, explanted rat lenses cultured with varying amounts of glucocorticoids. In the presence of 5 to $50 \mathrm{nM}$ prednisolone, an opacification developed in the lenses in a time- and concentration-dependent manner. In contrast, no morphological changes could be detected under similar incubation with 5 to $50 \mathrm{nM}$ of 4-pregnen$11 \beta, 17 \alpha, 20 \alpha, 21$-tetrol-3-one, a non-ketolic analogue in which the C-20 carbonyl is reduced to a hydroxyl group. Figure 2 shows the appearance of three representative lenses after $11 \mathrm{~d}$ of culture. Lens A shows no opacification and is typical of lenses incubated without prednisolone or with pregnen-tetrolone. Lenses $B$ and $C$ were incubated with 5 and $50 \mathrm{nM}$ prednisolone, respectively, and show a centrally located opacification that increases with prednisolone concentration. Morphological changes in the cultured embryonic chick lens also have been reported to be induced by high concentrations (1 $\mathrm{mM}$ ) of prednisolone (18).

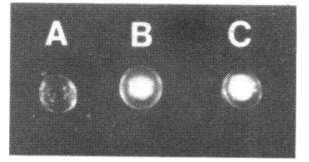

Figure 2. Three representative rat lenses after $11 \mathrm{~d}$ of culture. $A$ : A lens incubated without prednisolone. $B$ and $C$ : Lenses incubated with 5 and $50 \mathrm{nM}$ prednisolone, respectively. Lenses incubated with 5 to $50 \mathrm{nM}$ of the nonketolic analogue 4-pregnen-11 $\beta, 17 \alpha, 20 \alpha, 21$ tetrol-3-one had the appearance of lens A. The small light reflections visible in lens $A$ are artifacts of photography. 
Single lenses that were incubated with $50 \mathrm{nM}$ prednisolone were removed at intervals and the total proteins extracted into water-soluble, urea-soluble, and urea-insoluble fractions. As a function of time in culture, there is a decrease in the amount of water-soluble proteins and a commensurate increase in the amounts of urea-soluble and urea-insoluble proteins (Fig. 3). Control lenses incubated without prednisolone did not show any change. This result is consistent with previous studies showing that there is a decrease in water-soluble proteins with cataract formation in vitro and in vivo $(10,19)$.

Previous studies have demonstrated that glucocorticoids can react directly with lysine residues to form covalent addition products with albumin (7). The possibility that glucocorticoids might form covalent adducts with proteins in the intact rat lens was analyzed by culturing lenses in the presence of $5 \mathrm{nM}$ $\left[{ }^{3} \mathrm{H}\right]$ prednisolone. These lenses were then fractionated into water-soluble and urea-soluble fractions as described in Methods. After dialysis against a buffer containing $0.1 \%$ SDS, these fractions were analyzed for protein content and incorporated radioactivity. Figure 4 shows that there is a time-dependent increase in protein-associated prednisolone in the water-soluble and urea-soluble lens fractions. By $11 \mathrm{~d}$, the urea-soluble proteins contain somewhat more incorporated tritium than the proteins in the water-soluble fraction. Figure 4 also shows that in each fraction, virtually all the incorporated radioactivity is precipitable with antisera specific for proteins modified by prednisolone (described below). Therefore, the occurrence of tritiated proteins must be due to covalent modification by $\left[{ }^{3} \mathrm{H}\right]$ prednisolone, and not to $\left[{ }^{3} \mathrm{H}\right]$ prednisolone metabolism with subsequent incorporation of the tritiated intermediates into newly synthesized macromolecules.

The water-soluble, urea-soluble, and urea-insoluble extracts were then electrophoresed under denaturing conditions in the presence of $0.1 \%$ SDS. Figure 5 shows the Coomassie Blue staining of each lens protein fraction and the fluorographs of these fractions as a function of time the lens was in culture. Negligible changes were observed in the Coomassie Blue staining of the different lens protein fractions during incubation. Protein-bound $\left[{ }^{3} \mathrm{H}\right]$ prednisolone can be seen to be present in the water-soluble and the urea-soluble fractions. No incorporated radioactivity could be detected in the urea-insoluble fraction. The labeled urea-soluble proteins contain a slightly

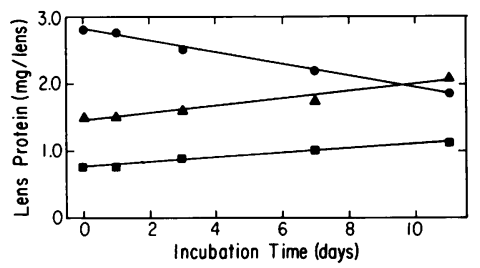

Figure 3. Single lenses incubated with $50 \mathrm{nM}$ prednisolone were removed at the indicated times and the total protein fractionated into water soluble, urea-soluble, and urea-insoluble proteins as described in

Methods. (๑): Water-soluble proteins; (₫): urea-soluble protein; (๑): urea-insoluble protein. Lenses incubated without prednisolone did not show any change.

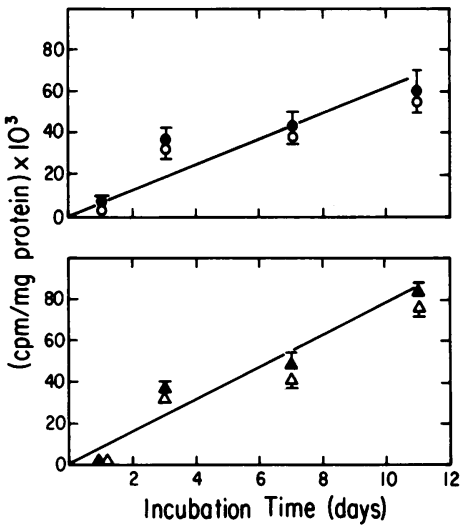

Figure 4. Lenses incubated

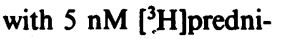
solone were removed at the indicated times and the proteins fractionated as described in Methods. The closed symbols show the incorporated radioactivity and the open symbols show the immunoprecipitable activity. $(\bullet, 0)$ : water soluble protein, $(\Delta, \Delta)$ : urea-soluble protein. Each point shows the mean \pm 1 SEM for duplicate determinations.

higher specific radioactivity than the labeled water-soluble proteins, and the incorporation of tritium into both protein fractions increases with incubation time. These results confirm the observations shown in Fig. 4. In both the water-soluble and the urea-soluble fractions, the two predominant species of $\left[{ }^{3} \mathrm{H}\right]$ prednisolone labeled proteins have an approximate molecular weight of 18,000 and 22,000 . By comparison with a previous description of rat lens proteins (20), it would appear that the $18,000-\mathrm{mol} w t$ protein can represent either $\alpha$ - or $\gamma$ crystallins and the 22,000 -mol wt protein represents a subunit of $\beta$-crystallins. A small amount of $\left[{ }^{3} \mathrm{H}\right]$ prednisolone incorporation is also detectable in a much higher molecular weight protein. The identity of this protein is unknown.

To detect prednisolone-protein adducts that form in vivo, we prepared polyclonal antisera to albumin modified by the nonenzymatic addition of prednisolone. In a previous study, high titer specific antisera was prepared against albumin modified in vitro by the estrogen, $16 \alpha$-hydroxyestrone (14). Incubation of prednisolone with albumin was found to yield an addition product that contained $\sim 3 \mathrm{~mol}$ prednisolone/mol

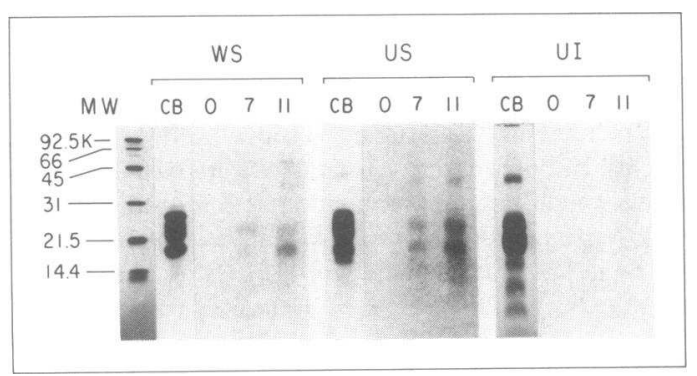

Figure 5. SDS polyacrylamide gel electrophoresis and fluorography of lens protein fractions after incubation of whole lenses with $5 \mathrm{nM}$ $\left[{ }^{3} \mathrm{H}\right]$ prednisolone, MW: molecular weight, WS: water-soluble fraction, US: urea-soluble fraction, UI: urea-insoluble fraction, CB: Coomassie Blue staining of each lens protein fraction. 0,7 , and $11=\mathrm{Gel}$ fluorographs after 0,7 , and 11 days of lens culture. 
albumin. Antisera was produced to this synthetic adduct and used in a competitive radioimmunoassay with $\left[{ }^{3} \mathrm{H}\right]$ prednisolone. A series of antigen inhibition curves is shown in Fig. 6. The antisera was found to have a higher affinity for free prednisolone than for the immunogen: prednisolone modified albumin. Equal reactivity was observed with prednisolone-protein adducts whether they were synthesized with or without $\mathrm{NaCNBH}_{3}$ (data not shown). Enzymatic digestion of prednisolone-albumin by proteinase $\mathrm{K}$ increased the reactivity of the prednisolone protein adduct 40 -fold, most likely by destroying a large portion of the interfering tertiary structure of the protein. A similar increase in reactivity was observed after enzymatic digestion of lens protein modified by incubation with prednisolone in vitro. The minimum detectable amount of antigen at the $95 \%$ confidence limit was calculated to be $0.10 \mathrm{pmol}$ for prednisolone and 0.33 pmol for prednisolone-peptides.

Table I summarizes cross-reactivity studies with several steroids and prednisolone-protein derivatives. Other glucocorticoids react with the antisera to a varying degree, although the 9-fluorocompounds, dexamethasone and betamethasone, react poorly $(0.1 \%)$. A possible complication in the use of the prednisolone-albumin immunogen is that $\mathrm{NaCNBH}_{3}$ may reduce additional Schiff base adducts that form at the C-3 position of prednisolone. This site would not normally be expected to form stable adducts with proteins under aqueous conditions. The antisera however, appears to be primarily recognizing a D-ring conjugated hapten since glucocorticoids with structural changes in ring $D$ (i.e., prednisolone hemisuccinate, 4-androsten-11 $\beta$-ol-3,17,dione) cross-react to a much greater degree than those with large changes in ring A (i.e., tetrahydrocortisol).

After determining that prednisolone can modify lens protein in vitro, we then used the antiprednisolone antisera to assay enzymatic digests of human lens proteins for the presence of prednisolone adducts. Normal and cataractous human lenses were homogenized and the proteins fractionated into water-

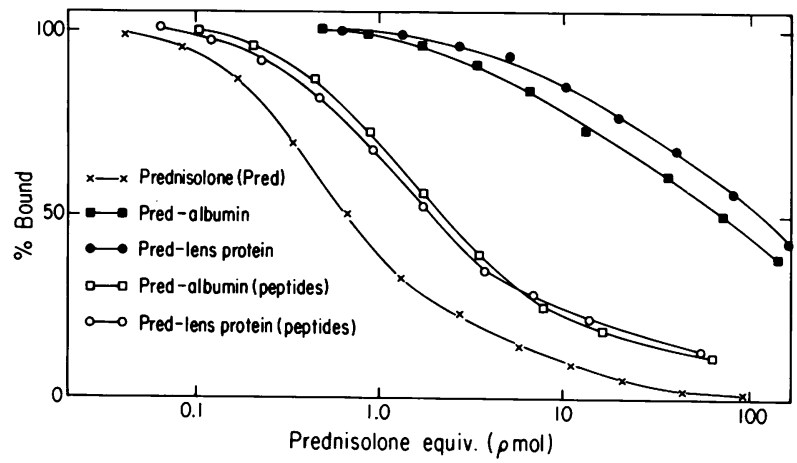

Figure 6. The relative percentage bound vs. log dose curves for antiprednisolone-albumin antiserum with five antigens using $\left[{ }^{3} \mathrm{H}\right]$ prednisolone as the competitor. Each point represents the mean of duplicate determinations.
Table I. Percent Cross-Reaction Relative to Prednisolone of Antiprednisolone-Albumin Antiserum with Selected Compounds

\begin{tabular}{ll}
\hline Compound & $\begin{array}{c}\text { Cross reactivity } \\
\text { at 50\% binding }\end{array}$ \\
\hline & $\%$ \\
Prednisolone & 100 \\
Prednisolone hemisuccinate & 41 \\
Cortisol & 32 \\
Prednisone & 18 \\
4-Androsten-11 $\beta$-ol-3,17-dione & 1.5 \\
Dexamethasone & 0.1 \\
Betamethasone & 0.1 \\
Tetrahydrocortisol & 0.04 \\
Prednisolone-albumin & 1.0 \\
Prednisolone-lens protein & 0.7 \\
Prednisolone-albumin (peptides) & 40 \\
Prednisolone-lens protein (peptides) & 41 \\
Dehydroepiandrosterone & $<0.001$ \\
Etiocholanolone & $<0.001$ \\
17 $\beta$-Estradiol & $<0.001$ \\
\end{tabular}

soluble, urea-soluble, and urea-insoluble portions. Low molecular weight material was removed by extraction with ethyl ether or extensive dialysis against $0.1 \%$ SDS. The water and urea soluble-lens protein fractions were then analyzed by competitive radioimmunoassay with $\left[{ }^{3} \mathrm{H}\right]$ prednisolone. These fractions and the urea-insoluble fraction also were assayed

Table II. Glucocorticoid Lens Protein Adducts in Human Lenses

\begin{tabular}{lcc}
\hline Lens type & N & $\begin{array}{c}\text { Urea-soluble } \\
\text { lens proteins }\end{array}$ \\
\hline Normal & 9 & ND \\
Cataractous & & \\
$\quad$ Traumatic & 1 & ND \\
Diabetic & 5 & ND \\
Senile & 11 & ND \\
Steroid induced & 7 & \\
& A & 45.3 \\
& B & 67.3 \\
& C & 5.3 \\
& D & 7.3 \\
& E & 6.2 \\
& F & ND \\
& G & ND \\
\hline
\end{tabular}

ND, Not detected at a sensitivity of 0.33 pmol prednisolone equivalents. Values are expressed as pmol prednisolone equivalents/mg lens protein. 
after digestion with proteinase $\mathrm{K}$. Antibody binding activity was found in the urea-soluble fraction of five of the seven steroid-induced cataracts assayed. The binding activity in these lenses was found to increase with enzymatic digestion in an identical manner as lens proteins modified with prednisolone in vitro. None of the normal, other cataractous lenses, or other lens protein fractions displayed antibody binding activity at an assay sensitivity of $0.33 \mathrm{pmol}$ of prednisolone equivalents. Table II expresses this activity in terms of prednisolone equivalents calculated from a standard curve of water-soluble lens proteins that had been modified by prednisolone in vitro and digested with proteinase $\mathrm{K}$. These values may not reflect prednisolone adducts alone since several of the lenses were obtained from patients who were receiving other steroids such as cortisone (lens A), betamethasone (lens C), and dexamethasone (lens F). The degree to which these steroid protein adducts contribute to the antibody binding activity cannot be determined, but is presumably low since these glucocorticoids were administered in much lower amounts and, in the case of dexamethasone and betamethasone, the antiserum reacts poorly with these steroids.

\section{Discussion}

Previous studies (7) have shown that steroids containing a ketol moiety, e.g., cortisol and $16 \alpha$-hydroxyestrone, can form stable, covalent adducts with protein amino groups. Using the phenomenon of nonenzymatic glycosylation as a model (21), it is apparent that long-lived proteins would be particularly vulnerable to the accumulation of steroid protein adducts. The fact that lens proteins have a low turnover rate (22), and that glucocorticoids appear to induce cataracts as an integral function of time and steroid dose (23), led us to investigate the possibility that glucocorticoid-protein adducts occur in the lens as a consequence of long-term glucocorticoid administration. The formation of these adducts, in turn, might be involved in the pathogenesis of steroid-induced cataracts.

Prednisolone was chosen for study as a model glucocorticoid. Cultured rat lenses were found to develop marked opacification when exposed to prednisolone over a range of 5 to $50 \mathrm{nM}$. In contrast, no changes could be induced by the non-ketolic derivative 4-pregnen-1 $\beta, 17 \alpha, 20 \alpha, 21$-tetrol-3-one. The development of opacification was accompanied by a decrease in the amount of water-soluble protein present in the lens. Morphologically, this opacification was centrally located and increased in size in a time- and concentration-dependent manner. This appearance differs from the posterior subcapsular changes that occur in the human in vivo. The occurrence of posterior changes has been attributed to a number of factors, such as the accumulation of the toxic agent in the vitreous or the attenuation of the epithelium with its basement membrane at the posterior pole, leading to a more facile penetration of the agent into the lens $(24,25)$. In an in vitro situation, the normal anatomic orientation of the lens is lost and the development of opacification may not exactly parallel the in vivo changes. We are currently attempting to define the precise anatomic localization of prednisolone adducts in these lenses. Recently, we have succeeded in inducing specific posterior subcapsular changes in the rabbit by the intravitreal injection of prednisolone. These lenses also show measurable levels of prednisolone-protein adducts (Bucala, R., M. Gallati, E. Cottier, and $\mathrm{A}$. Cerami, submitted for publication).

The addition of $5 \mathrm{nM}\left[{ }^{3} \mathrm{H}\right]$ prednisolone to the rat lens culture media resulted in the incorporation, with time, of tritium into both water-soluble and urea-soluble proteins. Over $98 \%$ of the protein bound radioactivity was precipitable with antiprednisolone antisera, indicating that the incorporated radioactivity must be due to covalent modification by $\left[{ }^{3} \mathrm{H}\right]$ prednisolone. Electrophoresis in the presence of SDS and gel fluorography showed that prednisolone reacts primarily with crystallins subunits. Greater incorporation of prednisolone was observed with membrane-associated (i.e., urea-soluble) crystallins. There are two possible explanations for this result. The first is that prednisolone may concentrate in the hydrophobic environment of the membrane and react preferentially with proximal membrane proteins. In a previous study, the estrogen $16 \alpha$-hydroxyestrone was found to react preferentially with cell membrane proteins when added in vitro to whole blood (8). The second possibility is that soluble crystallins, once modified by prednisolone, may undergo structural alterations that lead to precipitation and association with membranes. This possibility would account for the decrease in water-soluble protein that was observed to occur during prednisolone induced cataract formation in vitro. In the human lens prednisolone-protein adducts were detected only in the urea-soluble fraction. This may reflect fundamental biochemical differences between proteins in the rat and the human lens, or more likely, the preferential accumulation of stable prednisolone-protein adducts in the urea-soluble proteins over longterm exposure.

Although crystalline subunits were the only proteins observed by fluorography to be labeled by $\left[{ }^{3} \mathrm{H}\right]$ prednisolone, we cannot exclude the possibility that it is the modification of other proteins, present in much smaller amounts, which leads directly to cataract formation. The modification and inactivation of key metabolic enzymes or of membrane-associated ionophores, for example, might cause osmotic changes and produce the gross morphological appearance of cataracts.

To detect the occurrence of lens protein modified by prednisolone in vivo, a radioimmunoassay was developed for the measurement of prednisolone-protein addition products. Antisera was raised against a synthetic prednisolone-albumin conjugate and used in a competition radioimmunoassay with $\left[{ }^{3} \mathrm{H}\right]$ prednisolone. The antisera was found to be most specific for free prednisolone and for prednisolone covalently linked to proteins and small peptides. Lens proteins from 33 normal and cataractous human lenses were fractionated into water- 
soluble, urea-soluble, and urea-insoluble extracts. After removing low molecular weight material, the proteins were digested with proteinase $K$ and subjected to radioimmunoassay. Binding activity was observed in the urea-soluble proteins of five of the seven steroid-induced cataractous lenses assayed.

The cataractous lenses analyzed were from patients who had received relatively low doses of corticosteroids $(\sim 10 \mathrm{mg} /$ d) for a varying number of years. The highest measured levels of prednisolone-protein adducts were from two patients (A and B) who had been treated with prednisolone for $>8 \mathrm{yr}$. Of interest is that patient B had received only an ophthalmic preparation of prednisolone, demonstrating that topical as well as systemic routes of administration can lead to adduct formation in vivo. The two steroid-induced cataractous lenses $(F$ and $G$ ) that did not display antibody binding activity were obtained from patients who had received the lowest cumulative dose of glucocorticoids of the lenses assayed. Presumably, these lenses had levels of steroid adducts that were below the sensitivity of our radioimmunoassay $(0.33 \mathrm{pmol}$ prednisolone equivalents).

Modification levels of 5-67 pmol prednisolone/mg protein were observed in the human lens specimens. The identity of the proteins modified by prednisolone in the human lens remains to be determined. As in the case of the in vitro cataract, it is possible that the modification of a minor, but metabolically important protein species is the event that leads to cataract formation. In the cultured rat lens, visible lens changes were associated with a modification level of 1-10 $\mathrm{pmol} / \mathrm{mg}$ urea-soluble protein. Thus, macroscopic lens changes in both the cultured rat lens and the human lens are associated with approximately an equivalent degree of protein modification. The differences observed in the amount of steroid-protein adducts present in the human cataractous lenses is most likely the result of exposure to different cumulative doses of prednisolone. Other factors may play an important role in the onset of lens opacification. These include inherent biochemical differences in the susceptibility of the lens to protein modifcation, or in the ability of the lens to remain transparent despite high levels of protein modification. The simultaneous accumulation of other covalent addition products, perhaps as a result of nonenzymatic glycosylation or carbamylation, may influence the course of lens opacification. The report of a more rapid onset of unilateral cataract in the eye of diabetic patients who had been treated with glucocorticoids points to the possible additive effect of agents that can covalently modify proteins (26).

In conclusion, we have shown that prednisolone-protein adducts occur in the lens as a consequence of exposure to high levels of prednisolone in vitro and in vivo. The formation of these adducts correlates with the development of prednisolone-induced cataracts in the cultured rat lens and in the human lens. Further study is required to elucidate how these adducts might contribute to the lens changes that occur during cataractogenesis. Of significance is the possibility that gluco- corticoid-protein adduct formation may play a role in other toxic manifestations of long-term glucocorticoid therapy.

\section{Acknowledgments}

We are indebted to Drs. A. J. Bron, J. J. Harding, and V. Monnier for supplying us with steroid-induced cataractous lenses. We are grateful to Drs. V. Monnier, J. J. Harding, E. Cotlier, and R. Bellhorn for helpful discussions during the course of this study and to Dr. M. Brownlee for his comments on the manuscript. The expert secretarial assistance of Ms. Alice Striegel is greatly appreciated.

This work was supported by a grant from the Kroc Foundation and by grant PHS AM19655 from the National Institutes of Health.

\section{References}

1. Haynes, R. C., and F. Murad. 1980. Adrenocorticotropic hormone; adrenocorticortical steroids and their synthetic analogs; inhibitors of adrenocortical steroid biosynthesis. In Goodman and Gilman's The Pharmacological Basis of Therapeutics. A. G. Gilman, L. S. Goodman, and A. Gilman, editors. (Macmillan, New York, Sixth ed. 1366-1496.

2. Black, R. L., R. B. Oglesby, L. von Sallman, and J. J. Bunim. 1960. Posterior subcapsular cataracts induced by corticosteroids in patients with rheumatoid arthritis. J. Am. Med. Assoc. (JAMA). 174:166171.

3. Lubkin, V. L. 1977. Steroid cataract-A review and conclusion. J. Asthma Res. 14:55-59.

4. Spaeth, G. L., and L. von Sallmann. 1966. Corticosteroids and cataracts. Int. Ophthal. Clin. 6:915-929.

5. Ono, S., H. Hirano, and K. Obara. 1972. Presence of cortisolbinding protein in the lens. Ophthalmic Res. 3:233-240.

6. Ono, S., H. Hirano, and K. Obara. 1972-73. Further studies on the cortisol-binding protein in the lens. Ophthalmic Res. 4:193-198.

7. Bucala, R., J. Fishman, and A. Cerami. 1982. Formation of covalent adducts between cortisol and $16 \alpha$-hydroxyestrone and protein: Possible role in the pathogenesis of cortisol toxicity and systemic lupus erythematosus. Proc. Natl. Acad. Sci. USA. 79:3320-3324.

8. Bucala, R., J. Fishman, and A. Cerami. 1984. The reaction between $16 \alpha$-hydroxyestrone and erythrocytes in vitro and in vivo. Eur. J. Biochem. 140:593-598.

9. Obazawa, H. A., L. O. Merola, and J. H. Kinoshita. 1974. The effects of xylose on the isolated lens. Invest. Ophthalmol. 13:204-209.

10. Kramps, H. A., H. J. Hoenders, and J. Wollensak. 1976. Protein changes in the human lens during development of senile nuclear cataract. Biochim. Biophys. Acta. 434:32-43.

11. Bradford, M. M. 1976. A rapid and sensitive method for the quantitation of microgram quantities of protein utilizing the principle of protein-dye binding. Anal. Biochem. 72:248-254.

12. Laemmli, U. K. 1970. Cleavage of structural proteins during the assemble of the head of bacteriophage T4. Nature (Lond.). 227:680685.

13. Laskey, R. A., and A. D. Mills. 1975. Quantitative film detection of ${ }^{3} \mathrm{H}$ and ${ }^{14} \mathrm{C}$ in polyacrylamide gels by fluorography. Eur. J. Biochem. 56:335-341.

14. Bucala, R., and A. Cerami. 1983. Characterization of antisera to the addition product formed by the nonenzymatic reaction of $16 \alpha$ hydroxyestrone with albumin. Mol. Immunol. 20:1289-1292.

15. Abraham, G. E. 1975. Reliability criteria for steroid radioim- 
munoassay. In Radioimmunoassay of Steroid Hormones. G. Gupta, editor. Verlag Chimie, Weinheim, West Germany. 14.

16. Ebeling, W., N. Hennrich, M. Klockow, H. Metz, H. D. Orth, and H. Lang. 1974. Proteinase K from Tritirachium album limber. Eur. J. Biochem. 47:91-97.

17. Moore, S., and W. H. Stein. 1954. A modified ninhydrin reagent for the photometric determination of amino acids and related compounds. J. Biol. Chem. 211:907-913.

18. Edwards, A., J. D. Gupta, and J. D. Harely. 1973. Photomicrographic evaluation of drug-induced cataracts in cultured embryonic chick lens. Exp. Eye Res. 35:495-498.

19. Hu, T. S., P. Russell, and J. H. Kinoshita. 1982. In vitro incubation paralleling changes occurring during mouse cataract formation. Exp. Eye Res. 35:521-533.

20. Ocken, P. R., S.-C. J. Fu, R. Hart, J. H. White, B. J. Wagner, and K. E. Lewis. 1977. Characterization of lens protein. I. Identification of additional soluble fractions in rat lenses. Exp. Eye Res. 24:355367.
21. Monnier, V. M., and A. Cerami. 1983. Nonenzymatic glycosylation and browning of proteins in vivo. Am. Chem. Soc. 215:431449.

22. Wannemacher, C. F., and A. Spector. 1968. Protein synthesis in the core of the calf lens. Exp. Eye Res. 7:623-625.

23. Giles, C. L., G. L. Mason, I. F. Duff, and J. A. McLean. 1962. The association of cataract formation and systemic corticosteroid therapy. J. Am. Med. Assoc. 182:719-722.

24. Yanoff, M. 1975. Pathology of cataract. In Cataract and Abnormalities of the Lens. J. G. Bellow, editor. Grune \& Stratton, Inc., New York. 155-189.

25. Hollwich, F., A. Boateng, and B. Kolck. 1975. Toxic cataract. In Cataract and Abnormalities of the Lens. J. G. Bellows, editors. (Grune \& Stratton, Inc., New York. 230-243.

26. Yablonski, M. E., R. M. Burde, A. E. Kolkner, and B. Becker. 1978. Cataracts induced by topical dexamethasone in diabetics. Arch. Opthalmol. 96:474-476. 